\title{
BIOCHEMISTRY OF LOMBRICINE
}

\section{Occurrence of D-Serine in Lombricine}

L OMBRICINE (guanidinoethyl seryl* phosphate) 1 was isolated from earthworms (Lumbricus terres. tris) by Thoai and Robin", and on the basis of paper chromatographic identification of the products of acid hydrolysis the following structure was suggested :<smiles>N=C(N)NCCOP(=O)(O)CC(N)C(=O)O</smiles>

This structure has been confirmed by unequivocal synthetic routes using DL- and L-serine (Beatty and Magrath, following communication). For obvious reasons, it was assumed that the h-enantiomorph was present in the natural product; but comparison with the synthetic product indicated that this was not the case (following communication). It has now been found that the D-isomer is actually present.

A sample of natural lombricine ${ }^{2}(580 \mathrm{mgm}$.) was hydrolysed in a sealed tube in $6 \mathrm{~N}$ sulphuric acid at $110^{\circ} \mathrm{C}$. for $24 \mathrm{hr}$. The serine present in the hydrolysate was isolated using ion-exchange and paper chromatography to give a final yield of $42 \mathrm{mgm}$. This material was free from guanidinoethyl phosphate and other hydrolysis products as shown by paper chromatography, using appropriate solvent systems and sprays. Recrystallization from aqueous ethanol yielded crystals $\left([\alpha]_{D}=+7 \cdot 40^{\circ}\right.$ in water ; melted with decomp. at $217^{\circ}$, uncorr.) which were identical in chromatographic behaviour in a number of solvent systems with D-serine.

A sample of the crystalline material was examined for its ability to function as a substrate for a crude preparation of sheep kidney $\mathrm{D}$-amino-acid oxidase ${ }^{3}$. An authentic sample of L-serine was not oxidized by this preparation. In the case of the isolated material the amount tested $(3 \cdot 6 \mathrm{mgm}$.) yielded an oxygen uptake (over $45 \mathrm{~min}$.) identical with that of an equivalent amount of authentic D-serine. The D-amino-acid oxidase was without effect on natural lombricine, synthetic DL-lombricine and synthetic DL-aminoethyl seryl phosphodiester ${ }^{4}$.

Initial attempts to use an unfractionated hydrochloric acid hydrolysate product of lombricine as substrate for the enzyme failed because of the inhibitory quality of the hydrolysate. Whether this was due to some product(s) of hydrolysis or to some accidental contaminant is not known, but the result does cast doubt on the allocation of an I-configuration to the seryl moiety of aminoethyl seryl phosphodiester isolated from turtle muscle ${ }^{5}$. The evidence for this rests solely on the inability of a $\mathrm{D}$-amino-acid oxidase preparation to oxidize the serine component of an unfractionated snake venom hydrolysate of the compound. If, as has been suggested ${ }^{2}$, the aminoethyl seryl diester isolated from earthworms is the biological precursor of lombricine, it follows from the present results that, in the earthworm at least, the serine moiety of aminoethyl seryl diester would have a $D$-configuration.

The few claims for the presence of $\mathrm{D}$-amino-acids in animal tissues have not met with general accept-

- In this and the following communication the term 'servl' is used for convenience and refers to the '2-amino-2-carboxyethyl' group. ance $^{6-8}$. The configuration about the $\alpha$-carbon atom of the 'alanine' moiety of octopine has been considered by some to be $D^{-7,8}$, but this conclusion seems unwarranted on the basis of the evidence available This report, therefore, constitutes the first occasion on which a D-amino-acid has been unequivocally shown to exist in animal tissue.

The presence of $D$-serine in lombricine suggests that this isomer may also be present in other compounds (for example, phospholipids and proteins) in the earthworm and, indeed, that it may not be the only $\mathrm{D}$-amino-acid which occurs in this creature. It is hoped that work at present in progress will shed some light on these possibilities. The full report of this will be published elsewhere.

Iva M. BEaTTy

D. I. Magrath

A. H. ENNOR

1 Thoai, N. Y, and Robin, Y., Biochim. Biophys. Acta, 14, 76 (1954). Rosenberg H., and Fnnor, A. H., Biochem. $J$. (submitted for publication).

${ }^{3}$ Bender, A. E., and Krebs, H. A., Biochem. J., 46, 210 (1950).

Jones, E. E., and Lipkin, D., J. Amer. Chem. Soc., 78, 2408 (1956) ${ }^{5}$ Roberts, E., and Lowe, I. P., J. Biol. Chem., 211, 1 (1954).

- Miller. J. A. Cancer Res., 10, 65 (1950)

7 Meister, A., "Ann. Rev. Biochem.", 25, 29 (1956).

a Meister, A., in "Biochemistry of the Amino Acids" (Academic Press, New York, 1957).

Herbst, R. M., and Swart, E. A., J. Organ. Chem., 11, 368 (1946).

\section{Synthesis of DL- and L-Lombricine}

ON evidence based mainly on the paper chromatographic identification of the products of acid hydrolysis, it was concluded that lombricine was a mixed phosphodiester of serine and guanidinoethanol ${ }^{1}$. The amount of material isolated was small, and the configuration of the serine moiety was not investigated.

We wish to report the synthesis of DL- and L-lombricine by a route which confirms the structure allocated ${ }^{1}$ and further indicates that the seryl residue in natural lombricine has the D-configuration. DLand L-seryl aminoethyl phosphates were synthesized from the corresponding protected serine derivatives and $\mathrm{N}$-carbobenzoxyethanolamine by a 'staggered' reaction with monophenylphosphorodichloridate, according to the method of Jones and Lipkin ${ }^{2}$. Subsequent reaction with $\mathrm{O}$-methyl isourea in aqueous solution at approximately $p \mathrm{H} 11$ resulted in selective conversion of the aminoethyl residue in these compounds to a guanidinoethyl residue, giving DL- and L-lombricine in more than 70 per cent yield. Preliminary attempts to protect the $\alpha$-amino group of the seryl moiety during the reaction with O-methyl isourea, by forming a complex with copper (cf., for example, the preparation of arginine from ornithine ${ }^{3}$ ), led to extensive degradation of the molecule. Lombricine was found to be similarly unstable in the presence of copper, and the mechanism of the degradation is being investigated.

Both synthetic products erystallized from aqueous alcohol as colourless rods, the DL- melting at $216^{\circ} \mathrm{C}$. (decomp.) and the L- at $226^{\circ}$ (decomp.); natural lombricine $\mathrm{A}^{4}, 224^{\circ}$ (decomp.) (Thoai and Robin ${ }^{1}$ give $223-24^{\circ}$ ). All samples showed discoloration before melting and the melting point varied appreciably according to the rate of heating and state of subdivision. Analysis : calc. for $\mathrm{C}_{6} \mathrm{H}_{15} \mathrm{O}_{6} \mathrm{~N}_{4} \mathrm{P}: \mathrm{C}, 26 \cdot 6$; $\mathrm{H}, 5.5 ; \mathrm{N}, 20.8 ; \mathrm{P}, 11.5$ per cent; found: $\mathrm{DL}$ - : 